\title{
“Zooming In" on Children's Rights During a Pandemic: Technology, Child Justice and COVID-19
}

\author{
Nessa Lynch \\ Associate Professor, Faculty of Law, Te Herenga Waka - Victoria University \\ of Wellington, Wellington, New Zealand \\ nessa.lynch@vuw.ac.nz \\ Ursula Kilkelly \\ Professor, School of Law, University College, Cork, Ireland \\ u.kilkelly@ucc.ie
}

\begin{abstract}
The implementation of public health measures in response to the COVID-19 pandemic has impacted heavily on the operation of child justice systems and places of detention, creating new challenges in the safeguarding and implementation of children's rights. Yet, it has also been a time of innovation, particularly in the use of technology. Using case studies from Ireland and Aotearoa New Zealand, we discuss how technology has been used to maintain the balance between restrictive yet necessary public health measures and the operation of the child justice system. Examples include remote participation in remand hearings and trial and the use of "virtual visits" for children in detention.
\end{abstract}

\section{Keywords}

children's rights - COVID-19 - child justice - detention - technology 


\section{Introduction}

At the time of writing, in February 2021, the COVID-19 virus has affected over 100 million global citizens, caused over 2 million deaths (World Health Organisation, 2021) and is expected to continue its deadly trajectory for months or even years to come. Every country of the world has restricted or is restricting the freedom of movement and activities of its citizens, ranging from various stages of "lockdown", to travel restrictions and significant impacts on governmental, trade, commerce, educational and recreational activities (see, e.g. Grogan, 2021).

The global pandemic has had a significant impact on many aspects of children's rights (Campbell et al., 2020) but it is being acutely felt by vulnerable children. In April 2020, the Committee on the Rights of the Child warned of the 'grave physical, emotional and psychological effect of the covid-19 pandemic on children' and called on states parties to protect children whose vulnerability is further increased by the exceptional circumstances caused by the pandemic, including children deprived of liberty (Committee on the Rights of the Child, 2020). Non-governmental organisations and others have similarly called on states to take proactive measures to minimise the impact on children's rights, especially in the justice system (DCI, 2O2O; ENOC, 2020).

This contribution focuses on the rights of children in the child justice system, defined as the justice system encountered by children alleged as, accused of or recognised as having infringed the criminal law (Committee on the Rights of the Child, 2019, para. 5). As context, we outline the respective responses to COVID-19 in our home jurisdictions of Aotearoa New Zealand and Ireland and consider the salient principles of the human rights framework. We utilise the use of audio-visual links (AVL) as a case study - particularly how the technology is used to enable remote participation in justice processes and for family visits for children deprived of liberty. Given that the pandemic has hastened innovation and process agility, we are particularly interested in reflecting the lessons that may be learned from this experience so that the potential of technology to safeguard and promote children's rights in the child justice system can be harnessed for the future.

As for methodology, our research is taking place in the context of a rapidly evolving situation and set of circumstances, much of which has yet to filter into published literature or reported case law. For this reason, we draw on several informal and unpublished sources - in addition to guidance documents 
and media reportage, as academics with strong formal and informal linkages to the practice of child justice, we draw on our regular dialogue with professionals working in the system, on observations of practice in the justice system and indirectly on consultation with children themselves

Lastly, a note on terminology. Jurisdictions differ in terminology - we use the term "child" here to describe those aged less than 18 (Art. 1, UNCRC). As noted above, we use the term "child justice" as recommended by the UN Committee on the Rights of the Child in its recent General Comment on Children's Rights in the Child Justice System (2019).

2

\section{New Zealand and Ireland: Justice System Responses to the Global Pandemic}

Aotearoa New Zealand has had a 'science-led response' to Covid-19 (Geoghan et al., 2021). There was a strict lockdown (Alert Level 4) in place for a month from 23 March 2020, with the following two weeks at Alert Level 3, and then down to Alert Level 2 (restrictions on large gatherings, and contact tracing) by early June 2020 (New Zealand Government, 2021). There was a regional lockdown in the Auckland region in August 2020 and another in mid-February 2021. At the time of writing in late February 2021, a lockdown period of seven days was announced again for the Auckland region, with lesser restrictions for the rest of the country. Thus, while there has been a comparatively positive experience, the possibility of further outbreaks and further restrictions is live.

During "lockdown" periods, there are significant impacts on the operation of the criminal justice system, including the child justice system. Courts as public spaces are clearly an area of heightened risk for spread of the virus. In line with government requirements, restrictions on access to court buildings were put in place and remote participation was required or encouraged (Courts of New Zealand, 2021). In the large District Court jurisdiction (which includes the Youth Court), approximately 16,ooo court events were rescheduled and approximately 7,00o were adjourned during the March/April lockdown (District Court of New Zealand, 2020). The focus for all courts during the lockdown period was matters affecting personal liberty and time critical proceedings (Beck, 2020) and although Alert Levels 1 and 2 allow the justice system to operate more freely, it is still dealing with the significant delays that were caused by the lockdowns. Other in-person justice processes such as youth 
justice family group conferences, which particularly affect child defendants, have also been disrupted (Tinsley and Lynch, 2020).

New Zealand Police were observed to take a mainly educative approach to offending by children during the March to June lockdown periods (Office of the Children's Commissioner, 2020a) resulting in fewer charges and formal interventions. For children in youth justice custody (Aotearoa has four youth justice residences spread around the country), there were strategic efforts to use detention as a very last resort and to keep "bubble" arrangements small to protect children (Children's Convention Monitoring Group, 2021). There was a reported 30 per cent drop in custody numbers over the severest lockdown period, which can also be attributed to a sharp fall in offending over the "lockdown" period (Children's Convention Monitoring Group, 2021).

Ireland's experience of the COVID-19 pandemic has been very different. The virus arrived in Ireland on 29 February 2020, and the first death from coronavirus took place on 11 March 2020, prompting the first national lockdown, introduced on 12 March 2020, when schools were closed, remote working introduced and the closure of both non-essential retail and hospitality outlets. Travel was limited to a $2 \mathrm{~km}$ radius and the older and more vulnerable were asked to "cocoon". While the summer brought some reprieve, as society and the economy opened again, by Autumn of 2020 restrictions were back in place, in line with the second wave of the virus. Although schools remained open from September to December, a resurgence of the virus around the Christmas holiday period led to a third, lengthy period of severe public health restrictions, including the closure of all schools and childcare facilities, non-essential retail and all hospitality. At the time of writing, at the end of February 2021, schools are being reopened on a gradual basis, in line with the Government's Living with COVID Plan (Government of Ireland, 2021), but many other restrictions are expected to remain in place until Summer 2021 by which time the Vaccination Implementation Programme is expected to have advanced (Government of Ireland, 2020a).

The impact of CoviD-19 and the rolling imposition of severe public health restrictions have had a detrimental impact on children's rights in Ireland. Concerns about child poverty (Children's Rights Alliance, 2020), the detrimental and uneven impact of school closures on children's development and education (Doyle, 2020) and a deterioration in child mental health are particularly acute (McNally, 2020). There has been some focus on children living in particularly difficult situations (Ombudsman for Children, 2020), although children in the justice system, including in detention, have received relatively little public attention. 
In terms of the justice system, the Government introduced an Action Plan early in 2020 that identified the measures to be taken in both the courts and the prisons to prevent the spread of COVID-19 (Government of Ireland, 202ob). These included measures to increase remote working by the judiciary, improve communication with court users and scale back the work of the courts so that only urgent cases and those not involving witnesses would proceed. This has continued during the course of the pandemic, with the range of measures in place to maintain social distancing during court hearings having a knock-on effect on the court lists with obvious but as yet unquantified delays in the criminal process (The Courts Service of Ireland, 2021). Separate actions were identified early on with respect to the prisons (not including child detention) with regard to training for staff, managing visits and mitigating any virus outbreaks (Government of Ireland, 202ob) with varying levels of success.

Oberstown Children Detention Campus (Oberstown) is the national centre for children under 18 years in Ireland serving remand or detention orders. A unique national service based near Dublin, the capital city on the east of the country, Oberstown can accommodate 54 children although its average daily population during 2020 was 36 . Oberstown activated its emergency planning process in February 2020, and quickly moved to take a series of measures to reduce the risk of the virus coming onto the Campus, while preparing for an outbreak if it occurred. These included the use of the Director's powers under the Children Act 2001 to grant eligible children temporary release or permitted absence to minimise the numbers of children on the Campus. Children live in "pods" to minimise interaction across residential units and a range of public health and other measures have been in place to minimise the restrictive impact of CoviD-19 on the care and education provided.

Children in the child justice system are recognised under the United Nations Convention on the Rights of the Child (CRC) as a group in need of special protection. Their circumstances demand age-appropriate treatment and an adapted system of justice that safeguards their rights and interests under Article 40 of the CRC. In the child justice system, children have the same minimum rights as an adult (UN Committee on the Rights of the Child, 2019), but also have additional rights and protections based on their characteristics as children. Child justice systems must assure:

- Respect for children's rights to dignity and privacy (Art. 4O(1), 4O(2)(b)(vii) CRC;). 
- Non-discrimination (Art. 2, CRC).

- Treatment consistent with age and desirability of reintegration (Art. 4O(1), CRC).

- Best interests must be a primary consideration (Art. 3(1), CRC).

- Duty to hear and take account of the views of the child in all matters affecting the child (Art. 12(1); 40 (2) CRC).

- The child's right to a fair trial, with procedures and institutions specially adapted to the needs and circumstances of the child (Article $4 \mathrm{O}(2)(\mathrm{b})$, Article 4O(3) CRC).

All children have rights to education, healthcare and protection from harm, rights which are especially important for children deprived of liberty (Nowak, 2019). Detention must be a measure of last resort and for the shortest appropriate period of time (Art. 37(b)) and while deprived of liberty the child has the right to maintain contact with family through correspondence and visits 'save in exceptional circumstances' (Art. 37(c) CRC).

Children's rights in the child justice system are under threat in times of normality - particularly the rights of children accused of serious offending, who are often excluded from some of the protections of the child justice system (Lynch and Liefaard, 2020). Such rights are under additional threat during the CoviD-19 pandemic when the procedures, processes and timeframes of the justice system must give way to public health considerations, and normally high levels of scrutiny (inspections, media coverage, public hearings) are suspended or lowered. International children's rights law offers little guidance for how these competing considerations may be balanced although, according to the Committee on the Rights of the Child (the Committee) (2020, para 1):

International human rights law exceptionally permits measures that may restrict the enjoyment of certain human rights in order to protect public health. However, such restrictions must be imposed only when necessary, be proportionate and kept to an absolute minimum.

The Committee has called the pandemic an emergency, and this must underpin any analysis of the effects on rights in states parties (Lebret, 2020). In a pandemic, the state must also protect other human rights such as the right to the highest possible standard of health and fulfil its duty to prevent threats to public health (Forman and Kohler, 2020). Children's 'vulnerability is further increased by the exceptional circumstances caused by the pandemic' (Committee on the Rights of the Child, 2020, para. 7) and in addition to recommending the release of children from places of detention, where possible, the Committee has called for vigilance in respect of the suspension of children's 
visits from family. In particular, while noting that restrictive measures may be 'necessary in the short term', for public health reasons, it has cautioned that such limitations could have a 'marked negative effect on children' 'over long periods', and called for consideration to be given to a reassessment of the measures that prohibit such visits should the period of emergency be extended (Committee on the Rights of the Child, 2020, para. 8).

\section{Remote Participation and Children's Rights}

\subsection{Use of Audio-Visual Link (AVL) in the Child Justice System}

In New Zealand, remote participation replaced or supplanted in-person appearances where movement and travel restrictions were in place. Only a minority of child justice cases involve a court hearing due to extensive use of diversionary measures (Ministry of Justice, 2020). Remote participation in court has been legislatively empowered since 2010 (Courts (Remote Participation) Act 2010) and powers were further extended through Epidemic Notices and legislative amendments. For young defendants, the Oranga Tamariki Act 1989 places extensive duties on the Court and counsel to ensure understanding of the process and outcomes, including the provision of supports such as communication assistance where the young defendant has communication needs (Lynch, 2019). These legislative provisions align strongly with the Article 12 right under the CRC and broadly with the fair trial standard in Article 40.

The Courts of New Zealand (through the Chief Justice and the administrative Heads of Bench) issued guidelines and protocols for each alert level (Courts of New Zealand, 2021). The strictest lockdown period was relatively short (March and April 2020), so most matters were pushed forward until the courts could open again. Pursuant to the guidelines (Courts of New Zealand, 2021), during the strictest Alert Level 4, the Youth Court prioritised proceedings relating to restriction of liberty such as arrest, bail application, review of custody, secure care applications and early release hearings for children in detention. These were primarily by AVL, with a facility for children to appear in person at the nearest operating court venue if AVL was not available. Where a support person was sought during the Level 4 lockdown, if the presiding Judge approved the request, the support person would either attend the hearing from their own device (if they had the technological capability) or if not, attend the courthouse in person. Under the next level of lockdown, which allowed limited travel, the Youth Court continued to prioritise cases affecting the liberty of young people and those already in custody. Under Alert Level 2, numbers gathering were restricted - AVL appearances are no longer the default position, 
unless safety concerns or other circumstances necessitated this. Youth Court sittings at a Marae or Pasifika venue did not resume and instead were held at the courthouse, but Youth Advocates could request to have a cultural process incorporated into the hearing. Under Alert Level 1, court proceedings were back to normal, but have had to pivot quickly to AVL where "snap lockdowns" were put into place, such as in August 2020 and in February 2021.

In Ireland, where the prolonged nature of public health restrictions associated with COvID-19 has had a significantly disruptive effect on the justice system, AVL has been used to minimise children's physical interaction with the courts, and to limit their movement in and out of detention to attend hearings. The rolling nature of the public health restrictions makes it difficult to quantify the impact of such measures. While legislative provision was already in place to support remote hearings, the Government moved quickly to amend the law to expand this provision by enacting the Civil Law and Criminal Law (Miscellaneous Provisions) Act 2020. This Act sets out a range of conditions that must be satisfied before a remote hearing will take place, aiming to ensure that the proceedings will not be prejudicial to the parties or the interests of justice. The Act requires that remote hearings will only proceed where communication between the accused and his/her lawyer is not compromised and where the application in court is otherwise appropriate with regard, among other things, to the age of the relevant person and the person's mental capacity (s, 24(3)(e)).

Notwithstanding the long list of safeguards, much discretion rests with the judiciary as to when and in what form the remote hearings take place. Although the Act commits to this being informed by Practice Directions to be issued by the judiciary, no such guidance has yet been issued. Despite submissions made during the consultation process pointing to the risks that remote hearings pose to children's rights, the legislation makes no reference to children or their rights (aside from the general reference to age above). In practice, the availability of AVL facilities in court is an important factor in deciding whether to proceed with a remote hearing because even though Oberstown has audiovisual facilities, these are not universally available in courts around the country. More recently, a mobile telephone application has been developed to make it possible for children to participate remotely even where AVL facilities are not available, expanding the potential use of remote hearings. Clearly, technology continues to evolve in line with the needs of the justice system during CoviD-19 and this makes it even more important that the implications of such hearings for children's rights are given careful consideration.

\subsection{Remote Participation: the Issues for Children's Rights}

What impact did this rapid pivot to remote participation have for children's rights? Under Article 40 of the CRC, children have the right to fair trial, 
including the right to present a defence and to effective participation in the criminal process (Committee on the Rights of the Child, 2019). Although all defendants, including children, have a right to be present at their own trial, this does not necessarily require attending court in person. Even when present, however, a significant gap can remain between the requirement to ensure justice that is accessible to children and children's experience of their rights in this context (Liefaard, 2020). Giving effect to this right under New Zealand's law means the requirement for simple measures such as being able to hear and/or see adequately, or tailored measures such as translation services and communication assistance (Tinsley and Lynch, 2020). In Ireland, similarly, the Children Act 2001, s. 96(1)(a) requires that courts dealing with children charged with offences have regard to the principle that 'children have rights and freedom before the law equal to those enjoyed by adults and, in particular, a right to be heard and to participate in any proceedings of the court that can affect them'. Measures have been taken to adapt court proceedings to ensure children's understanding of and participation in the process, with varying results (Kilkelly, 2008).

There is a body of literature on the impact appearing in court proceedings via AVL can have on children's rights, particularly participation. Children's characteristics mean that navigating the in-person court process, even where it is adapted to their age and circumstances, is challenging. Even though the state has a duty to ensure that children's right to participate in court proceedings is protected, research has shown that they find it difficult to understand and engage in the criminal process (Forde, 2018). Challenges with communication and comprehension are amplified in the formal courtroom setting where their demeanour and behaviour can be misunderstood. Their undeveloped capacity can mean that they struggle to appreciate the gravity of their circumstances and their judgement can be influenced more by short-term gains, like having the hearing over quickly, than a long-term consideration of what is in their interests.

Remote participation can exacerbate these issues for all defendants (McKay, 2018; Rossner et al., 2021) but particularly for children (Children's Court of Victoria, 2015; Walsh, 2018). AVL has been found to have a negative impact on the ability of a child to participate and understand the proceedings, whilst also undermining the relationship of trust between the lawyer and child (Walsh, 2018). Walsh's focus group study of Queensland lawyers in the youth justice system (2018) found that child clients reported not being able to converse with their lawyers in private during proceedings, raising doubts as to whether their young clients could follow the proceedings or seek support where required. A lawyer's capacity to provide adequate support may be diminished or compromised (Page and Robertson, 2016). Children may not appreciate the 
seriousness of the proceedings due to a lack of meaningful interaction and children's safety and wellbeing may not be able to be safeguarded appropriately (Standing Committee for Youth Justice, 2018). Numerous studies (Lynch, 2016; Lount et al., 2018) show high rates of neuro-disability, traumatic brain injury, low literacy and communication in the population of children who offend - leading both to injustice and to low rates of compliance with orders and bail conditions. Where these children do not appear in person, and have limited time to consult with legal representation, disability and problems with effective participation might not be picked up, and the right to a fair trial ultimately could be undermined.

\subsection{Children's Views on the Use of AVL in Court Proceedings}

The Committee on the Rights of the Child has called on states parties to 'provide opportunities for children's views to be heard and taken into account in decision-making processes on the pandemic' (Committee on the Rights of the Child, 2020, para. 11). Only by hearing directly from children about their experiences (Cuevas-Parra, 2021), can a full understanding be reached about the implications of AVL for children's rights.

In October 2020, the Advocacy Officer at Oberstown Children Detention Campus undertook consultation with children about their experiences of remote hearings as part of a process to monitor the impact on their rights of COVID-19 restrictions. Eleven children in Oberstown with experience of video link court appearances, all boys under 18 years, were asked about the best thing about video link court appearances, the worst thing and if they could change anything about the process, what would it be.

The common theme from the consultation was that, with one exception, the children did not understand what was happening in court during their video-link hearing. All except one child said they had no idea what was going on in the court and explained the feeling that they were just sitting there 'looking at a TV'. One child, by contrast, indicated that it was an overall positive experience for him and that he much preferred it to attending court in person. His experience was unique, however, and may have been influenced by the fact that his was an appeal hearing as a result of which the process was strengthened by him enjoying access to his lawyer by simultaneous telephone while also seeing the court on screen. This meant that he could mute the court, as required, in order to consult confidentially with his legal representative. As a result of these measures, the child found that the experience was a positive one, where the anxiety that he normally associated with attending court in person was removed. 
Of the majority who were unhappy about the remote hearing process, three said that they were happy not to have had to make the trip to court - which can involve a long journey which disrupts their attendance in school and their daily routine - and for them, this was the best thing about AVL. Two would have been happy to make the trip so that they could see family and the other for the opportunity to smoke cigarettes. Ten children said that not seeing their family was the worst thing about appearing in court remotely; eight added that they missed out on being able to smoke. Seven children highlighted that being able to speak with their solicitor was something that they would change in relation to the remote hearings, because they reported not being able to get advice or ask questions to determine what was happening over video-link. Two children felt they would be confident enough to speak with the judge if something needed to be said, but the other nine children said that they would not be comfortable to do this on a video link with the court. One child contacted their solicitor following their hearing concerned that the outcome of their case had been impacted by them not feeling able to speak to the court or to their lawyer during the court hearing.

In this small sample of 11 children who had experience of remote court hearings, the majority reported not having 'any idea what was happening' during the process and did not feel part of the hearing. Many children highlighted not being able to have their lawyer with them (they were in the court instead) as a concern and all but one reported that they would not be able to speak with the judge if they needed to.

An evaluation of the New Zealand experience is apparently being conducted by Oranga Tamariki (the state care agency), but anecdotal reports indicate children identified some positive outcomes related to remote participation over "lockdown", particularly around less disruption in moving from residence to court, less opportunity for absconding, and reduction of general disruption (Children's Convention Monitoring Group, 2021). The New Zealand system means that key functions of the justice system (such as proof of offence and recommendations on outcome) are conducted by a youth justice family group conference so these were also conducted through remote participation in part or in full. Oranga Tamariki (2020) released guidelines on conducting family group conferences in a virtual or dual-delivery model, including privacy, confidentiality and participation.

In summary, children's experiences of remote participation in court and other processes probably mirrored or exacerbated existing issues with participation and comprehension. The Irish consultation presents worrying findings about the extent to which children understood proceedings over AVL. While 
the experience of one child presents some positive learning - for instance in making a simultaneous telephone link available to enable confidential conversations with his lawyer - it is not clear whether this adjustment/extension to other cases would be sufficient to remedy the deficits in the process more generally. At the very least, AVL would appear to jeopardise the child's right to effective participation in the court process and have significant effect on the right to fair trial. This is especially important where the consequences are high-such as in a full trial or in a sentencing hearing and it is not clear that these deficits can be remedied. For more procedural or administrative hearings, such as a re-remand or ordering of a court report, it may represent a useful compromise between the disruption that a journey to and from court involves and the impact on the child's involvement in the process. In all cases, however, compliance with the child's rights must require that adequate support and information is available to the child, in line with international standards such as the European Guidelines on Child-friendly Justice to ensure that she/he can follow the process and understand its implications. Resources should be made available to explain the process to the child in an accessible manner and consideration should be given to appointing a trained intermediary to help the child to navigate the system. These and other ideas for supporting the child's participation in remote hearings are discussed further below.

\section{Virtual Visits - Family Contact for Children in Custody}

International children's rights standards recognise the importance for children of maintaining contact with their family when in detention and Article 37 (c) of the CRC recognises the right of every child to maintain contact with family through correspondence and visits, save in exceptional circumstances. According to the Committee on the Rights of the Child, such 'exceptional circumstances' should be clearly described in law and not left to the discretion of the authorities (Committee on the Rights of the Child, 2019, para. 94). Both the European Rules for Juveniles Subject to Sanctions and Measures and the UN Rules for the Protection of Juveniles Deprived of Liberty (the Havana Rules) place this right in the context of the child's contact with the outside world as well as the right to maintain relations with their family. In particular, both instruments recommend that children have the right to communicate with family members in an unrestricted manner through correspondence and regular visits. These standards recognise the importance of family contact for children deprived of liberty, while recognising that there may be times when limits are justified. There is little doubt that the risks that a global pandemic 
poses to the safety and security of child detention may justify the removal of physical visits, as outlined by the Committee on the Rights of the Child (2020, para. 8). At the same time, any limits on such visits must be proportionate with the public health situation so that, where possible, for instance, screened visits should be used in preference to removing physical visits altogether. In terms of the proportionality of these restrictions, the Committee on the Rights of the Child has also highlighted that while they may be seen as necessary 'in the short term', over long periods, it has warned, 'they will have a marked negative effect on children', requiring them to be reassessed where the emergency situation is prolonged (2O2O, para. 8),

In Aotearoa New Zealand, AVL was used to facilitate contact with whānau (family members) where public health restrictions did not allow in-person visits. New Zealand's legislation places considerable emphasis on maintaining and strengthening links with the child's family. A survey of 47 children in the youth justice residence during the Alert Level 4 lockdown found that children enjoyed video-calling as it was a new initiative, but not all had equitable access to video-calling facilities (Office of the Children's Commissioner, $202 \mathrm{ob}$ ). Children also reported that they were worried about the health of family members, particularly older members of the family and were worried about delays and disruptions to family visits (Children's Convention Monitoring Group, 2021).

When Ireland entered Level 5 public health restrictions in March 2020, Oberstown moved quickly to introduce virtual visits between children and their families. The Campus was agile in its approach, quickly identifying the preferred platform and securing the necessary IT equipment to make the facility available in all residential units. A key element in the success of this approach was the time spent helping children and their families to understand the necessity of the decision. In line with the guidance of the Committee on the Rights of the Child (2020, para. 11), children were helped to 'understand what (was) happening' so that they could feel that they were 'taking part in the decisions that [were] being made in response to the pandemic'.

Regular engagement with families was also used to provide reassurance that their children were being well cared for and that any difficulties navigating the technology were quickly addressed. Apart from maintaining contact with their families, one of the immediate additional benefits of introducing virtual visits was that the children got to interact with wider family members - such as younger siblings and grandparents - who they might not otherwise see during physical visits. They also had the opportunity to see their home, their dog and so on, helping them to connect more with their families in familiar surroundings. As one child explained: 'I don't really mind not getting visits, on the video 
call. I get to see my mam dad and brother together. If it goes on for a long time I might change but at the moment I'm very happy'.

For families who might have to travel long distances to visit their child in Oberstown, this had the significant benefit of enabling more frequent contact with their children, without the expense and time that would normally involve. As one child explained, 'I have more visits now as my family don't have to travel'. Children in Oberstown, which is the only child detention centre in Ireland, come from right across the country and families can sometimes have to travel for several hours, from Donegal in the north or from Kerry in the south to see their children (Oberstown Children Detention Campus, 2019). This places the value of virtual visits into its wider context and highlights how technology, where it is available to families, can enable a child to maintain these important relationships.

Despite these benefits, replacing face-to-face visits with video-calling is not a long-term solution and it can have long lasting consequences on children's relationships with family. In this regard, while children's experiences of virtual visits in Oberstown were very positive initially, the longer usage continues, the more concern evolves that some children may becoming detached from their families. As anticipated by the Committee on the Rights of the Child (2020), it is vital that this situation is reassessed in order to mitigate permanent harm to children's family relationships.

There is little doubt that the cost for children's rights of the global pandemic will be wide and deep, and felt most acutely by those most vulnerable. As this article illustrates, there has been a cost to children in the child justice system of being unable to attend court in person and having personal relationships with family disrupted. At the same time, innovative and agile practice helped to minimise the risk of harm to children. For example, the use of AVL prevented the need for children's transport in and out of court, reducing the health risk to the child and the risk to other children in the detention facility. It also prevented the delay of proceedings, which could impact on children, potentially prolonging their deprivation of liberty.

covid-19 prompted rapid innovation in court systems than any could have anticipated (Sourdin and McNamara, 2020) and, looking to the future, reflections are already underway as to how much of this will remain. It is undeniable that pre-existing plans for remote participation will be catalysed by the pandemic. As Rossner et al (2021) note: 
The "new normal" for courts is likely to involve a mix of in-person hearings and remote interactions, using phone or video, supported by greater use of electronic documents and asynchronous online procedures [INTERNAL REFERENCES OMITTED].

The pandemic experience demonstrates that for short court appearances such as bail or remand hearings, AVL is effective in reducing the trauma of attending court and the disruption and risk of transporting children to and from court. This could, if used appropriately, outweigh the negative effects of appearing via AVL. Where in-demand experts such as psychiatrists can join remotely, AVL could also mean that proceedings move faster and criminal charges determined more efficiently in line with the child's sense of time. Further, in Aotearoa New Zealand, the state agency Oranga Tamariki (2020) foreshadows that post-pandemic there are ways in which remote participation could still be used for family group conferences, giving examples such as where a victim is reluctant to attend due to anxiety about a confrontation, prospective non-attendance of family or victims due to difficulty with childcare or transport, or to include individuals who have had difficulty with keeping calm during previous family group conferences. For remote participation in justice proceedings, it is clear that children have additional needs for support to participate effectively and meaningfully. A good practice example is the tailored and easily understood guidance produced by Talking Trouble (2020) during the lockdown in New Zealand. This assists children in understanding the particular context in which they are being asked to participate. Engagement with the judiciary around these issues in Ireland is also likely to result in the introduction of further good practice.

AVL has been used to enable important relationships with family to be maintained for children deprived of liberty. These maintained a level of normality for children, when other restrictions limited their activity - such as during school closures - and helped to reassure them also that their families were well. While virtual visits are not a substitute for in-person visits, especially given the importance of one-to-one contact for children's development, there is little doubt that a blended or combined approach will help to maintain stronger family relationships for children deprived of liberty, especially where long distances are involved.

It will take some time for the long-term impact of CoviD-19 on children's rights to be fully understood. While the child justice system will undoubtedly require a "COVID dividend" to remedy the disproportionate impact on children's rights in this area, what is important is that positive innovations developed out of necessity are not lost in a return to the way things were before. 


\section{Acknowledgements}

Associate Professor Lynch wishes to acknowledge Tamara Wilson-Tasi for her research assistant work on this project.

Professor Kilkelly is grateful to Laura Lanigan for her research assistance on this project. The authors would also like to thank Oberstown Children Detention Campus for allowing us to share young people's views on their experiences.

\section{References}

Beck, A., "Covid19 and the courts", New Zealand Law Journal 2020, 177.

Campbell, S., Cicero Oneto, C., Saini, M. P. S., Attaran, N., Makansi, N., Passos Dos Santos, R., Pukuma, S. and Carnevale, F. A., "Impacts of the CoviD-19 pandemic on children: An ethical analysis with a global-child lens", Global Studies of Childhood 2020: 2043610620976142 .

Children's Convention Monitoring Group, Getting it Right - Children's Rights in the COVID-19 response (2021): https://www.occ.org.nz/publications/reports/ childrens-rights-in-covidig.

Children's Court of Victoria, Guidelines for Video-Conferencing: Criminal Division Video Link Hearings (20 April 2015).

Children's Rights Alliance, COVID 19 runs the risk of plunging thousands more families into poverty (2020). Available at: https://www.childrensrights.ie/resources/ press-release-covid-19-runs-risk.

Courts of New Zealand, Protocols: What courts are doing during COVID-19 alert levels (2021). Available at: https://www.courtsofnz.govt.nz/publications/announcements/ covid-19/court-protocols/.

Cuevas-Parra, P., "Thirty years after the UNCRC: children and young people's participation continues to struggle in a COVID-19 world", Journal of Social Welfare and Family Law 2021, 1-18.

Defence for Children International, The Impact of Covid-19 on Children's Rights. Report from DCI Sections (Geneva, DCI, 202O).

District Court of New Zealand, covID-19 Alert Level 4 - What happened in the District Court (2020). Available at: https://www.justice.govt.nz/assets/Documents/ Publications/3oxzvk7r2r-COVID19-Alert-Level-4-in-the-District-Court-datasummary-v1.o.pdf.

Donoghue, J., "The rise of digital justice: Courtroom technology, public participation and access to justice", The Modern Law Review 2017 (80(6)), 995-1025. 
Doyle, O., COVID-19: Exacerbating Educational Inequalities? (2020). Available at: https:// publicpolicy.ie/papers/covid-19-exacerbating-educational-inequalities/.

European Network of Ombudspersons for Children (ENOC), Children's rights in the context of the COVID-19 outbreak (2020). Available at: http://enoc.eu/wp-content/ uploads/2O2O/O4/ENOC-Bureau-statement-on-CR-in-the-context-of-the-COVID19-outbreak-FV.pdf.

Forde, L., "Realising the Right of the Child to Participate in the Criminal Process", Youth Justice 2018 (18(3)), 265-284.

Forman, L. and Kohler, J. C., "Global health and human rights in the time of CoviD-19: Response, restrictions, and legitimacy”, Journal of Human Rights 2020 (19(5)), 547-556.

Geoghegan, J. L., Moreland, N. J., Le Gros, G. and Ussher, J. E., “New Zealand's scienceled response to the SARS-CoV-2 pandemic", Nature Immunology 2021 (22(3)), 262263. DOI: https://doi.org/10.1038/s41590-021-0o872-x.

Government of Ireland, covid-19 Vaccination Programme (2020a). Available at: https://www.gov.ie/en/publication/bf337-covid-19-vaccination-strategy-andimplementation-plan/.

Government of Ireland, National Action Plan in response to covID-19 (2020b). Available at: https://www.gov.ie/en/publication/47b727-government-publishes-national-actionplan-on-covid-19/.

Government of Ireland, covid-19 Resilience and Recovery 2021: The Path Ahead (2021), Available at: https://www.gov.ie/en/campaigns/resilience-recovery-202O2021-plan-for-living-with-covid-19/.

Grogan, J., Power and the COVID-19 Pandemic - Introduction \& List of Country Reports, VerfBlog, 2021/2/22. Available at: https://verfassungsblog.de/power-and-the-covid19-pandemic. DOI: 10.17176/20210222-154018-o.

Kilkelly, U., "Youth Courts and Children's Rights: The Irish Experience", Youth Justice $2008(8(1)), 39-56$.

Kilkelly, U. and Liefaard, T. (eds.), International human rights of children (Singapore: Springer, 2019).

Lebret, A., "COviD-19 pandemic and derogation to human rights", Journal of Law and the Biosciences 2020 (7(1)). Available at: https://doi.org/10.1093/jlb/lsaao15.

Liefaard, T., "Juvenile justice from an international children's rights perspective", in W. Vandenhole, E. Desmet, D. Reynaert and S. Lembrechts (eds.), Routledge International Handbook of Children's Rights Studies (Routledge, 2015), 250-272.

Liefaard, T., "Child-friendly Justice and Procedural Safeguards For Children in Criminal Proceedings New Momentum For Children in Conflict With the Law?", Bergen Journal of Criminal Law and Criminal Justice 2020 (8(1)), 1-17.

Lount, S.A., Hand, L., Purdy, S. C. and France, A., “Tough talk:Youth offenders' perceptions of communicating in the Youth Justice system in New Zealand", Australian \& New Zealand Journal of Criminology 2018 (51(4)), 593-618. 
Lynch, N., Neurodisability in the youth justice system in New Zealand: How vulnerability intersects with justice, in Dyslexia Foundation of New Zealand. Summarising the Contributions of Participants at the 2016 Neurodisabilities Forum, Hosted by DFNZ in Wellington (2016) (vol. 12).

Lynch, N., "Protective Measures for Children Accused or Convicted of Serious Crimes", in W. O'Brien and C. Foussard (eds.), Violence Against Children in the Criminal Justice System: Global Perspectives on Prevention (Routledge, 2019).

Lynch, N. and Liefaard, T., "What is Left in the 'Too Hard Basket'? Developments and Challenges for the Rights of Children in Conflict with the Law", The International Journal of Children's Rights 2020 (28), 89-110. DOI: https://doi. org/10.1163/15718182-02801007.

McKay, C., The pixelated prisoner: Prison video links, court 'appearance' and the justice matrix (Routledge, 2018).

McNally, T., 70\% of primary school parents concerned about impact of COVID-19 on children's mental health, The Journal.ie (2020). Available at: https://www.thejournal. ie/70-primary-school-parents-concerned-about-mental-health-of-children5131799-Jun2o2o.

Ministry of Justice (2020) Youth Justice Indicators - Summary Report. Wellington, Ministry of Justice, December 2020. https://www.justice.govt.nz/assets/ Documents/Publications/Youth-Justice-Indicators-Summary-Report-December2020-FINAL.pdf.

New Zealand Government, Legislation and key documents (2021). Available at: https:// covid19.govt.nz/updates-and-resources/legislation-and-key-documents/.

Nowak, M., United Nations Global Study on Child Deprived of Liberty (Geneva: United Nations, 2019).

Office of the Children's Commissioner, Supplementary information regarding the impact of COVID-19 on children's rights in Aotearoa New Zealand, for the United Nations Committee on the Rights of the Child (2020a). Available at: https://www.occ. org.nz/assets/Uploads/Office-of-the-Childrens-Commissioner-SupplementaryReport-to-the-UNCRC-on-COVID-19-for-NZ-LOIPR-June-2020.pdf.

Office of the Children's Commissioner, OPCAT 'virtual' monitoring under COVID-19 Alert Level 4 Youth Justice residences, 3-30 April 2020, (2020b). Available at: https://www. occ.org.nz/assets/Uploads/OPCAT-COVID-Youth-Justice.pdf.

Ombudsman for Children, Direct Division. Life in Lockdown, a report on the views and experiences of children living in Direct provision accommodation during the Covid-19 pandemic (Dublin: oco, 2020). Available at: https://www.oco.ie/app/ uploads/2020/12/15469-OCO-Life-in-Lockdown_Interior_V4.pdf.

Oranga Tamariki Evidence Centre/Behavioural Insights Team, Navigating virtual participation: Guidance note on effectively coordinating FGCS with a combination of in-person and virtual participation (2O2O) Available at: https://www.orangatamariki. 
govt.nz/assets/Uploads/About-us/Research/Latest-research/Virtual-FGCs/VirtualFGC-guidance.pdf.

Page, E. and Robertson, C., Appearing in Court via Audio Visual Link: Issues for Young People (2016). Available at: https://law.uq.edu.au/files/38147/Appearing-in-courtby-AVL-issues-for-young-people-PageRobertson-June2016.pdf.

Rossner, M., Tait D. and McCurdy M., "Justice reimagined: challenges and opportunities with implementing virtual courts", Current Issues in Criminal Justice 2021, 1-17.

Sourdin, T., Li, B. and McNamara, D. M., "Court innovations and access to justice in times of crisis", Health policy and technology 2020 (9(4)), 447-453.

Standing Committee for Youth Justice, “They just don't understand what's happened or why": A report on child defendants and video links (April 2018).

TalkingTrouble,COVID-19communicationresourcesforOrangaTamariki(updated forLevel 3) (2020). Aavailable at: https://talkingtroublenz.org/presentations-publications/ covid-19-communication-resources-for-oranga-tamariki.

The Courts Service of Ireland. (2021). Available at: www.courts.ie.

Tinsley, Y. and Lynch, N., "Remote justice? Criminal proceedings in a pandemic", Newsroom (21 May 2020).

Toebes, B., Forman, L. and Bartolini, G., "Toward Human Rights-Consistent Responses to Health Emergencies: What Is the Overlap between Core Right to Health Obligations and Core International Health Regulation Capacities?", Health and Human Rights $202022(2), 99$.

UN, United Nations Rules for the Protection of Juveniles Deprived of Their Liberty (Havana Rules) adopted by the General Assembly, 2 April 1991, A/RES/45/113.

UN Committee on the Rights of the Child, General Comment No. 24: Children's rights in the child justice system (CRC/C/GC/24) (18 September 2019).

UN Committee on the Rights of the Child, CRC Covid-rg Statement (2020). Available at: https://www.ohchr.org/en/hrbodies/crc/pages/crcindex.aspx.

United Nations High Commissioner for Human Rights, Emergency Measures And covid-19: Guidance: Topics In Focus Emergency Measures And Covid-19 (27 April 2020).

Walsh, T., "Video Links in Youth Justice Proceedings: When Rights and Convenience Collide", Journal of Judicial Administration 2018 (27(4)), 161-181.

World Health Organization (2021). Available at: https://www.who.int/emergencies/ diseases/novel-coronavirus-2019. 